PONTIFÍCIA UNIVERSIDADE CATÓLICA DO RIO DE JANEIRO

Reestruturação Organizacional no setor 2.5

\author{
Caio Reis de Oliveira
}

Trabalho de Conclusão de Curso

Centro de Ciências socials - CCS

DEPARTAMENTO dE AdMINISTRAÇÃO

Graduação em Administração de Empresas 
Caio Reis de Oliveira

\title{
Reestruturação organizacional no setor 2.5
}

\author{
Trabalho de Conclusão de Curso
}

Trabalho de Conclusão de Curso, apresentado ao programa de graduação em Administração da PUC-Rio como requisito parcial para a obtenção do título de graduação em Administração.

Orientador: Ciro Torres

Rio de Janeiro novembro de 2018. 


\section{Agradecimentos}

Gostaria de agradecer primeiramente a minha família por ter me ajudado e me apoiado ao longo da faculdade. Agradecendo especialmente à minha Tia avó, Belinha, que me deu a possibilidade de estar cursando essa faculdade e à minha mãe que desde a infância foi a responsável, sozinha, por me cobrar e incentivar aos estudos e também na vida.

Muito obrigado aos meus amigos da PUC-Rio e da Stone House por terem me auxiliado nesta trajetória ao longo desses anos.

Agradeço ao meu orientador Ciro Torres, por ter aceitado me orientar e por estar sempre disposto a ajudar com sua experiencia.

E por fim, agradeço a Pontifícia Católica do Rio de Janeiro, universidade da qual me orgulho de ter cursado administração e pelos grandes profissionais que a faculdade oferece. 


\section{Resumo}

O trabalho de quarenta páginas, Reestruturação organizacional no setor 2.5, realizado por Caio Reis de Oliveira, teve como objetivo estudar uma organização real em desenvolvimento. Focou no tema de estrutura organizacional e abordou também os processos organizacionais. $O$ objetivo foi analisar a atual condição da empresa e propor soluções ou melhorias. Sendo essas pautadas por teorias presentes em material bibliográfico e pelos conhecimentos adquiridos durante a faculdade de Administração na PUC-RJ. A pesquisa foi qualitativa tendo como entrevistados gestores da organização. A análise de resultados e propostas de soluções foram embasadas em conhecimentos teóricos de autores como Tachizawa e Kerzner nos livros Organização flexível e Gerenciamento de projetos, respectivamente.

Estrutura organizacional; Gerenciamento de projetos; PMBOK; Organização Flexível; Reestruturação.

\section{Abstract}

The forty pages work, Organizational Restructuring in Sector 2.5, developed by Caio Reid e Oliveira, aimed to study a real organization in development. Focused on the theme organizational structure and also in processes. The objective was to analyze the conditions of the company in order to propose solutions or improvements. The bases are bibliographical materials and the expertise acquired during the graduation in Business Administration at PUC-RJ. The research was qualitative. Managers of the organization were interviewed. The analysis of the results was done through a series of information about techniques of research and project management respectively.

Organizational Structure; Project Management.; PMBOK; Flexible Organization; Restructuring 


\section{Sumário}

1 Introdução

1.1. Introdução ao tema …..............................................................................................

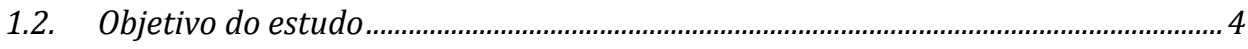

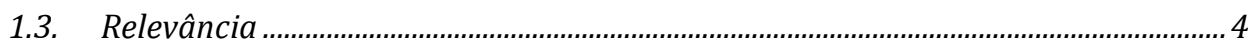

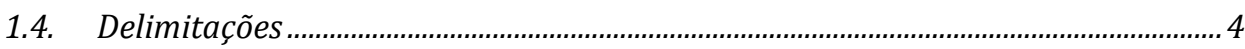

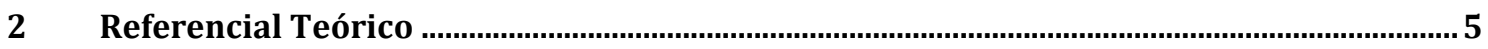

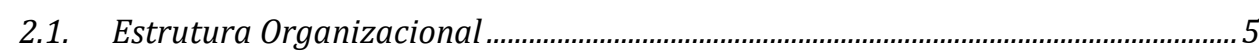

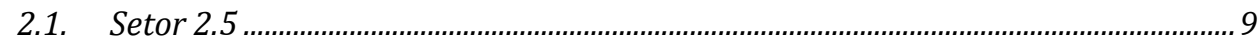

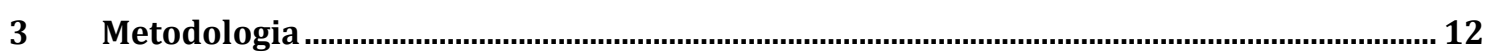

3.1. A Coleta de dados................................................................................................. 12

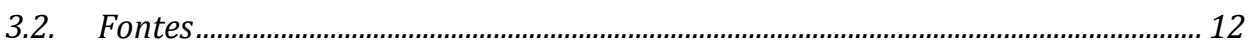

3.3. Procedimentos e Processos ...................................................................................... 13

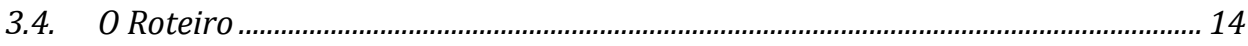

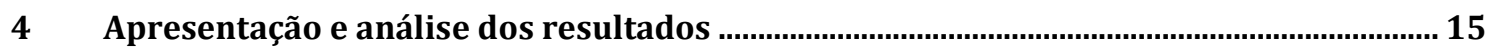

4.1. A Organização

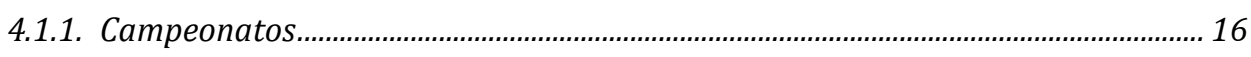

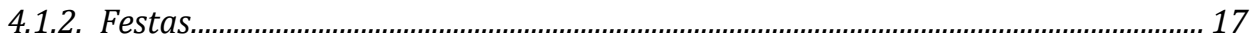

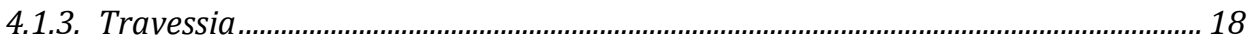

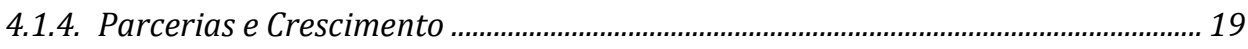

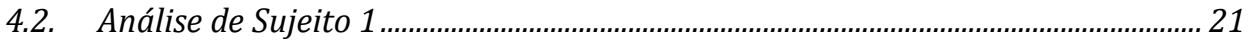

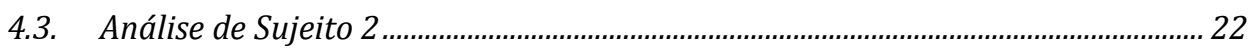

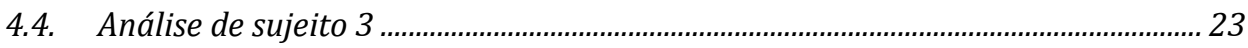

4.5. Análise dos resultados .................................................................................................. 24

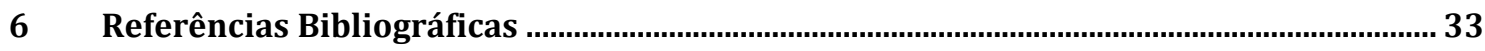

$7 \quad$ Anexos 


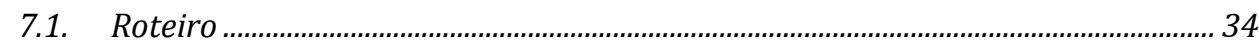

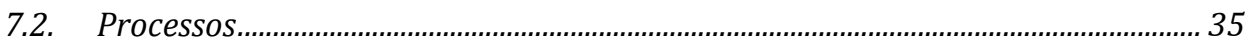

7.3. A Casa de Pedra ..................................................................................................... 35

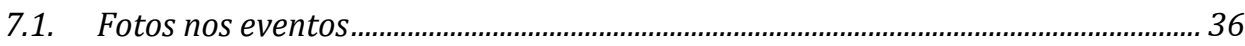

\section{Lista de Figuras}

Figura 2 Organograma Antigo da Stone House fonte: Acervo Stone House ............... 15

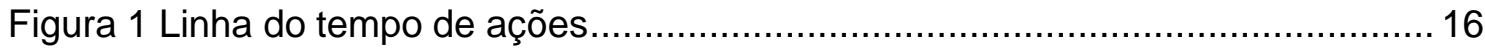

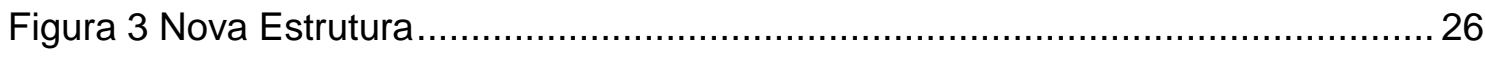

Figura 4 Stone House; Fonte: Acervo Stone House ............................................. 36

Figura 5 Festa do Campeonato; Fonte: Acervo Stone House ..................................... 36

Figura 6 Tubo durante o campeonato; Fonte: Acervo Stone House........................... 37

Figura 7 Chegada da travessia; Fonte: Acervo Stone House.................................... 37

Figura 8 Pegada do bem; Fonte: Acervo Stone House .......................................... 38

Figura 9 Saída da travessia; Fonte: Acervo Stone House........................................ 38 


\section{Introdução}

\subsection{Introdução ao tema}

O trabalho teve como foco de estudo a estrutura organizacional e processos de uma organização em desenvolvimento denominada Stone House.

A organização é fundamentada em 3 pilares, esporte, arte e sustentabilidade. Alinha os pilares através da realização de eventos como campeonatos de surf, travessias com o objetivo de coletar lixo, ações sociais de incentivo à educação e cultura, consultoria de sustentabilidade em eventos entre outras ações.

Em todos os eventos os pilares se relacionam de alguma maneira, trazendo à luz do público a importância da sustentabilidade através do esporte e da arte.

O objetivo central do trabalho foi a reestruturação da empresa adequando estrutura organizacional à atividade fim; levando em conta o tamanho e forma como ela trabalha. Para identificar o formato mais adequado foi necessário realizar uma leitura embasada em teorias de autores da área de organizações e também de Projetos (área em que a empresa atua); como Tachizawa e Kerzner, respectivamente.

A pesquisa foi elaborada através de um roteiro e entrevista semiestruturada com diretores da organização. A partir daí foi possível entender melhor as necessidades da organização e planejar e implementar um redesenho organizacional otimizando a organização e dando mais força ao seu planejamento estratégico.

A empresa é pertencente a um setor novo e inovador conhecido como setor 2.5 ou dois e meio, onde é possível encontrar os negócios sociais. 
Ao longo do trabalho será possível também ter uma breve noção desse novo setor. Por ser um tema recente foi interessante trazer à tona seu significado e seu papel na economia e na sociedade. Tem como principal característica o propósito de desenvolver soluções para desafios socioambientais enfrentados pela comunidade. Apesar de possuir características predominantes no terceiro setor, o setor dois e meio se diferencia principalmente pelas organizações terem fins lucrativos, característica atrelada ao segundo setor. Daí vem o nome setor dois e meio com um mix de características presentes tanto no segundo quanto no terceiro setor. O empreendedorismo nesse setor deve ter como característica principal gerar impacto social. A partir desse impacto os negócios sociais buscam também a sustentabilidade financeira.

Além dessa introdução, a presente monografia conta também com mais seis capítulos e quatro anexos.

O capítulo seguinte expõe o referencial teórico usado para embasar o trabalho. É composto principalmente pelo tema de reestruturação organizacional e pelo subtema setor dois e meio.

É apresentada a ótica de Kerzner no livro Gerenciamento de projetos, incluindo os motivos ou indicadores que apontam para a necessidade de uma reestruturação; além da estrutura mais adequada para a organização Stone House, foco do estudo. Ainda na reestruturação de Kerzner é necessária uma readequação dos processos através de conceitos a serem aplicados com a finalidade de implementar de maneira correta a nova estrutura. Tachizawa demonstra em seu livro Organizações Flexíveis algumas técnicas que são fundamentais para que uma organização com estrutura projetizada e com alta demanda de projetos, se adapte rapidamente e supra qualquer tipo de demanda, seja com a realocação do próprio pessoal ou com a busca por parceiros e apoiadores ou terceirizações para viabilizar a realização das tarefas em sua totalidade. 
Com relação ao tema setor dois e meio pode-se analisar a importância e relevância desse setor nos âmbitos da sustentabilidade: econômico, social e ambiental. Apesar dos empreendedores desse setor terem postura similar a das ONGs, esses não dependem de doações para realizar suas ações e têm o direito de recuperar o capital investido incluindo a lucratividade como forma de viabilizar os projetos.

No terceiro capítulo é apresentada a metodologia de pesquisa, procedimentos e processos utilizados para a estruturação do questionário e coleta de dados, as fontes e a forma de apresentação do roteiro das entrevistas semiestruturadas. Além disso é exposto o método utilizado para a transcrição das entrevistas, que foram sintetizadas buscando resumir e focar no tema abordado pelo estudo.

No capítulo seguinte pode-se obter uma visão mais detalhada a respeito da organização Stone House e dos projetos; e como as parcerias alavancaram o crescimento da organização. São demonstradas as análises baseadas nas entrevistas com os gestores; e o resultado das análises com a proposta embutida de um redesenho da estrutura e de processos organizacionais.

No capítulo de conclusões pode-se identificar as melhorias obtidas pela organização, provenientes do presente estudo e do planejamento e execução das propostas expostas pelo trabalho. As mudanças no modus operandi da organização e principalmente a diferença notada pelo aumento da capacidade de agregar novos projetos.

Ao final é possível ver as referencias bibliográficas que embasaram o trabalho teoricamente e também os anexos com fotos; falando sobre a casa de pedra onde tudo começou e onde são realizadas etapas dos eventos; por fim a sugestão de processos a serem adotados, esses são fundamentais para que a nova estrutura mantenha o bom desempenho. 


\subsection{Objetivo do estudo}

O estudo teve o objetivo de otimizar o andamento dos projetos de uma organização denominada Stone House pertencente ao setor 2.5, através da análise de sua estrutura e dos processos organizacionais. A partir dessa análise, propor melhorias e adequação dos mesmos ao modelo atual do negócio, visando melhorar a eficiência e eficácia desde o planejamento até a execução dos projetos através da aplicação de um redesenho da estrutura organizacional e também dos processos a serem adotados pela organização com o intuito de efetivar as mudanças.

\subsection{Relevância}

O estudo deu suporte a empreendedores e gestores do setor 2.5, principalmente na área de projetos, para analisarem sua estrutura e planejarem ações baseando-se em um resultado proveniente de uma análise referente aos impactos da mudança da estrutura organizacional e dos processos com a finalidade de melhorar o desempenho da área de projetos, tendo em vista que esta é a área de atuação da organização.

\subsection{Delimitações}

O estudo se restringiu a uma empresa pertencente ao setor dois e meio que atua principalmente com a realização de projetos de cunho social, cultural e ambiental na cidade do Rio de Janeiro. Não serão realizadas análises financeiras, tendo em vista que o tema principal é reestruturação organizacional. $O$ trabalho foi direcionado para organizações da área de projetos. 


\section{Referencial Teórico}

\subsection{Estrutura Organizacional}

De acordo com (Kerzner, 2011), nos últimos anos houve uma revolução secreta na introdução e no desenvolvimento de novas estruturas organizacionais, percebeu-se que, por natureza, as organizações devem ser dinâmicas e capazes de responder às mudanças ambientais se reestruturando de acordo com a necessidade. Isso ocorre por diversos fatores, o que mais se relaciona com a organização em foco no estudo seria o melhor controle de recursos, levando em conta que a empresa possui diversos projetos e produtos.

Há cinco indicações gerais que apontam para a ineficácia de uma estrutura tradicional de acordo com (Kerzner, 2011), são elas:

1 Não cumprimento de prazos
2 Especificações de desempenho não atendidas
3 Especialistas mal explorados e sobrecarregados
4 Indivíduos culpando uns aos outros por atrasos
5 Indivíduos insatisfeitos com a realização de projetos

Dentre essas opções podemos observar que na organização estudada, a falta de um plano estruturado de ação, metas e medidores de desempenho fazem com que apareçam os problemas citados acima, tendo em vista que não há uma direção de projetos que cobre os gerentes de projetos, deixando-os muito "soltos" gerando falta de comprometimento.

\footnotetext{
"Os behavioristas argumentam que não há uma estrutura única melhor que atenda aos desafios das organizações de amanhã. A estrutura utilizada, no entanto, deve ser a que otimize o desempenho da empresa, alcançando um equilíbrio entre as necessidades sociais e técnicas." (Kerzner, 2011, p. 58)
} 
A reestruturação organizacional, é recomendada quando surgem problemas desta natureza, porém deve ser pensada previamente de maneira que o ambiente social dentro da empresa seja levado em conta e não só aspectos técnicos. Ou seja, não basta pensar friamente nos cargos e posições sem antes avaliar a empatia entre os grupos de projetos, permitindo assim um desenvolvimento melhor para cada projeto individualmente. Falar que as ações não são exatamente individualizadas, mas que opiniões pessoais têm que estar alinhadas com o foco da ação e não seguir linhas diferentes de raciocínio para um mesmo objetivo.

\begin{abstract}
"Há uma vasta variedade de modelos organizacionais para reestruturação da administração. O método correto depende das pessoas na organização, das linhas de produtos da empresa e da filosofia da administração. Uma organização precariamente reestruturada pode romper canais de comunicação que podem ter levado meses ou anos para serem construídos; causar a reestruturação informal, criando, assim, novos poder, status e posições políticas; e eliminar a satisfação no trabalho e os fatores motivacionais em um nível que resulta em completo descontentamento." (Kerzner, 2011, p. 59)
\end{abstract}

Para pensar em uma reestruturação, Kerzner preparou uma lista de verificações que busca explorar o clima social e a relação entre o ambiente e a empresa, são elas:

1- Que tarefas demandam controle rigoroso e se essas devem ser realizadas de maneira eficaz?

2- Quais as necessidades e as atitudes de quem realiza as tarefas?

3-Quais os efeitos dos mecanismos de controle na motivação e desempenho das pessoas?

4- Quais os agrupamentos sociais identificados? Estes são importantes para motivação e desempenho?

5- Qual aspecto precisa ser integrado como tarefa global? 
6- Que medições são adequadas para melhorar o desempenho e motivar adequadamente?

7- Quais as medições que irão verificar se as mudanças estão sendo satisfatórias?

As respostas para essas perguntas não são de fácil obtenção. Para que haja a aplicação de uma reestruturação adequada, é necessário o método da tentativa e erro, pela ligação direta com fatores sociais e indivíduos diferentes, pode ser que os resultados sejam alterados rapidamente, e com isso haja a necessidade de adequações até mesmo durante o processo de reestruturação. A volatilidade do comportamento humano deve ser levada em conta para que a empresa esteja pronta para agir rapidamente e identificar problemas durante a reestruturação.

Ainda nesse tópico de reestruturação, deve-se ressaltar que "qualquer que seja o modelo organizacional selecionado finalmente, devem ser desenvolvidos canais formais, para que cada indivíduo tenha uma clara descrição da autoridade, do dever e da responsabilidade necessários para que o trabalho prossiga.". (Kerzner, 2011, p. 66).

A organização atualmente conta com diversos projetos, cada um com um tipo de produto diferente.

O modelo de estrutura projetizada, segundo (Kerzner, 2011, p. 66) é idealmente adequado para empresas que possuem "orientação a projetos". Nesse tipo de organização o trabalho é designado a pessoas ou unidades que "fazem o seu trabalho", "em uma organização projetizada, a autoridade para a tomada de decisão e a coordenação fica com o líder do projeto. (Kerzner, 2011, p. 67).

Para o desenvolvimento de uma estrutura projetizada, segundo (Kerzner, 2011, p. 66), "é necessário que os participantes passem tempo integral em seus projetos, gerando um alto grau de lealdade, métodos rápidos para resolver conflitos, acesso livre e claro de comunicação entre os gerentes". 
"Conforme cada projeto chega ao encerramento, as pessoas ficam apreensivas e se esforçam para provar o seu valor para a empresa desempenhando acima do esperado" (Kerzner, 2011, p. 66).

De acordo com Tachizawa "o modelo clássico-burocrático, fundamentado essencialmente na separação entre planejamento e execução e na divisão do trabalho por especialização" ( (Takizawa, 1997, p. 97) vem se mostrando um modelo ultrapassado, tendo em vista que "a não participação do pessoal envolvido na execução operacional em atividades de planejamento prejudicava a qualidade do mesmo, além de criar insatisfação naquele pessoal." (Takizawa, 1997, p. 97). Esta ligação entre planejamento e execução é fundamental na produção de eventos e serviços prestados pela organização estudada. Levando em conta que a visão de quem executa pode ser uma ferramenta para prever situações que necessitam processos formais e demandam atenção, que pode passar despercebida aos olhos do planejamento. Isso ocorre devido ao planejamento ser feito inicialmente com uma visão macro do evento, e depois deveria passar para uma visão mais restrita a cada etapa, como um olhar de lupa em cada processo do evento. É nessa fase que o pessoal da parte operacional tem grande valor, pois está acostumado com conflitos que podem não ter sido levados em conta em níveis de planejamento.

\begin{abstract}
"Uma das alternativas que se apresenta como viável, fruto de projetos de consultoria desenvolvido pelos autores em empresas de diferentes setores econômicos, é um modelo de organização flexível ... É uma forma organizacional que propõe a identificação e segregação dos processos produtivos dos processos de apoio, e, para os primeiros, a identificação dos que são realmente estratégicos." (Takizawa, 1997, p. 98).
\end{abstract}

No tópico de organização flexível, a organização se utiliza atualmente principalmente das parcerias, segundo (Takizawa, 1997, p. 104) "recomenda-se concretizar parcerias com empresas e entidades externas, no sentido de que as mesmas complementam as atuais atividades desenvolvidas internamente pela empresa visando ao atendimento do cliente.". Atualmente, em todos os eventos a empresa age corretamente criando laços com instituições que possuem 
semelhanças ideológicas para concretizar as ações e projetos, isso viabiliza os eventos através da redução de custos e da atração e inclusão de novos grupos de clientes provenientes das parcerias com outras empresas e pessoas.

De acordo com (Meo, 2015) "diversos empreendedores passaram a executar seus negócios em consonância com 0 capital social, ou seja, levando em conta a capacidade de cultivar valores comuns, de preservar e fortalecer a cultura local, de construir instituições eficientes e flexíveis e de atuar com cooperação"... "Apesar de ser estritamente social, reconheceuse que esse capital pode se transformar em valor econômico e gerar eficiência produtiva, comercial ou empresarial, o que resulta em riqueza social, renda e produção." (Meo, 2015).

Isso ocorreu de maneira orgânica na organização em estudo no período de um ano e meio de sua criação, principalmente por ser um sentimento de necessidade mútuo tanto entre os idealizadores dos projetos, quanto no público presente no meio em que a organização está inserida. Esse alinhamento de pensamento entre os organizadores e os stakeholders foi fundamental para viabilizar os projetos.

\subsection{Setor 2.5}

Tradicionalmente, a economia era basicamente constituída por 3 setores sendo eles o primeiro, composto pelo estado, o segundo composto por empresas e o terceiro que comportava ONGs e organizações sem fins lucrativos. Atualmente o nascimento e crescimento de empresas que unem características tanto do terceiro setor como objetivos de melhorias sociais, como do segundo, onde há fins lucrativos, essas empresas sociais são conhecidas atualmente como o setor dois e meio.

"Os negócios sociais vêm surgindo como uma nova tendência do empreendedorismo atual. O termo negócios sociais foi cunhado pelo economista e vencedor do Prêmio Nobel da Paz 
de 2006 Muhammad Yunus (2010). Para ele, negócios sociais são empreendimentos que necessariamente têm o impacto social como missão. Yunus (2010) acredita que os negócios sociais são uma das importantes formas de resolver problemas sociais e de melhorar a vida de muitas pessoas." (Sucupira, 2015)

Os Negócios Sociais têm o objetivo de resolver problemas sociais, esses são gerados principalmente pela falta de participação efetiva do governo na sociedade. Para sanar esses problemas as organizações do setor dois e meio se utilizam de métodos de negócios como criação ou venda de serviços e produtos diferenciados. Abordam temas que muitas empresas desprezam. A criatividade envolvida nesse setor propulsiona a criação de soluções rentáveis. Além disso, vale ressaltar a criação de emprego em condições dignas de trabalho como uma obrigação nesse tipo de empreendimento, que inclui em si as três esferas da sustentabilidade.

Os temas mais abordados no setor dois e meio são os desafios sociais relacionados às áreas de educação, saúde, nutrição, ambiental habitação e serviços financeiros.

A seguir está disposta uma tabela indicando os sete princípios dos negócios sociais por Yunus

- "O objetivo do negócio será redução da pobreza ou mais problemas (como educação, saúde, acesso a tecnologia e meio ambiente) que ameaçam as pessoas e a sociedade; não a maximização dos lucros.

- Financeira e economicamente sustentável

- Investidores recebem de volta somente o valor investido. Nenhum dividendo é pago além do dinheiro investido.

- Depois que o investimento for devolvido, o lucro da empresa fica na empresa para ampliação e melhorias.

- Ambientalmente consciente. 
- Colaboradores recebem valor de mercado com melhores condições de trabalho.

- ... fazer tudo isso com alegria."

(Yunus, 2010)

Uma dificuldade nesse setor é a mensuração dos resultados sociais, que muitas vezes não podem ser avaliados com simples indicadores financeiros. É preciso criar métricas que avaliem o impacto gerado por uma ação; intervenção ou iniciativa, de maneira que estejam alinhadas com os interesses dos investidores, dos empreendedores e principalmente do público que está sendo beneficiado diretamente por essas ações. Assim sendo é preciso estipular parâmetros e medidores de desempenho e satisfação para ambos os stakeholders envolvidos nos projetos.

De acordo com o INEI (Instituto Nacional do Empreendedorismo e Inovação):

\begin{abstract}
"O setor da economia que interliga as atividades sociais e ambientais com a lucratividade, de forma inclusiva, é chamado de 2.5. Ele é considerado um intermediário entre o segundo e terceiros setores, sendo formado, portanto, por empresas que, em sua constituição jurídica, têm, ao mesmo tempo, fins lucrativos e objetivos sociais inclusivos. Ou seja, é o setor privado movido pela consciência social e ambiental, cujos novos empreendimentos chamamos de Startups 2.5."
\end{abstract}

A organização Stone House se enquadra no setor dois e meio, pois tem um forte viés social, promovendo educação ambiental e incentivando políticas de incentivo à preservação do meio ambiente e também a outros fatores sociais como cultura, arte e esporte. Além disso ela tenta de diversas formas buscar a sustentabilidade em suas três esferas: econômica, social e ambiental. "Uma organização sustentável precisa ser economicamente lucrativa, ambientalmente correta e socialmente responsável”. (Zenone, 2006) . 
As ações são partes da gestão e não apenas pontuais. A sustentabilidade é a excelência na otimização dos recursos em busca do alcance dos objetivos.
"Os desafios da sustentabilidade além do levantamento e da aplicação adequada de recursos financeiros, implica investimento no desenvolvimento das pessoas que fazem parte da organização, melhorando a qualidade dos serviços $e$ adequando-os às necessidades das comunidades." (Félix R. G., 2010).

A partir desses conceitos e comparações com o modus operandi da organização, foi possível enquadrar a empresa no setor 2.5. Assumindo que a lucratividade foi alinhada à proposta de sustentabilidade exposta pela organização através de seus projetos e ações, almejando melhorias ao meio em que ela está inserida e também apoiando outras instituições que praticam trabalhos nobres nos campos da sustentabilidade.

\section{$3 \quad$ Metodologia}

\subsection{A Coleta de dados}

As entrevistas e a coleta foram realizadas na própria sede da organização, em outubro de 2018, consistiu em três entrevistas semiestruturadas, uma com cada gestor (indicados no item 4.3) separadamente.

\subsection{Fontes}

Os entrevistados são pessoas que possuem grande entendimento a respeito da organização. São elas: 
Sujeito 1 - CEO e cofundador da organização e estudante de oceanografia da UERJ.

Sujeito 2 - Coordenador de patrocínios e estudante de Administração da PUCRJ.

Sujeito 3 - Coordenador de logística e estudante de engenharia na PUC-RJ.

\subsection{Procedimentos e Processos}

Foi conduzida uma pesquisa exploratória voltada à diretores e coordenadores da empresa, com o intuito de buscar melhor entendimento a respeito de como a empresa opera e se a estrutura organizacional é adequada para o atual modelo de negócio.

A pesquisa realizada foi qualitativa. Teve como objetivo buscar maior entendimento referente à complexidade do problema, buscando opiniões, pensamentos e sentimentos através de perguntas abertas. Assim sendo, foi possível focar no ponto de vista de pessoas que estão presentes e em contato com o dia a dia na organização.

A entrevista semiestruturada teve como base um roteiro que consiste em uma sequência de perguntas direcionadas à estrutura organizacional e aos processos. Possibilitando o andamento de maneira orgânica; buscou naturalidade para possibilitar um melhor entendimento e dar liberdade aos entrevistados para acrescentarem pontos que julgassem importantes.

Foi destacada a importância e a relevância deste trabalho para que melhorias pudessem de fato, serem aplicadas à organização.

O roteiro está exposto ao final do trabalho no anexo 1.

As respostas transcritas na tabela de apresentação foram redigidas tomando como base as entrevistas gravadas em áudio. Para melhor entendimento do leitor. Assim sendo, foi reduzido o número de palavras aumentando a objetividade e 
ressaltando os pontos pertinentes ao trabalho em foco. Após redigir os textos das respostas, os entrevistados tiveram acesso e aprovaram os mesmos; para que fossem expostos na tabela como resultados da pesquisa.

\subsection{O Roteiro}

O Roteiro de pesquisa levou em conta 0 ambiente, a relação que o entrevistador possui com os entrevistados e os temas a serem abordados, assim sendo, a escolha por um roteiro de entrevista semiestruturada visando um bate-papo descontraído Isso promoveu a abertura de espaço aos interlocutores para não só responder, mas realmente transpassar suas opiniões pessoais além da visão profissional na empresa. Buscou-se dessa maneira, diagnosticar os pontos de conflitos não só no âmbito prático e teórico, mas também no social. Assim como indicar soluções para os temas abordados.

Três grandes temas principais foram abordados, são eles, a estrutura organizacional, processos organizacionais e por fim, pessoas. As perguntas foram direcionadas a estes temas pois se ligam diretamente ao foco de estudo da monografia

As perguntas foram abertas, ou seja, planejadas de maneira não restritiva, com o intuito de estimular os entrevistados a discursarem cada vez mais a respeito dos temas.

A estrutura Organizacional da imagem abaixo é a estrutura organizacional da empresa. Foi mostrada aos participantes antes dos mesmos começarem a responder às perguntas para que relembrassem como era a estrutura na teoria.

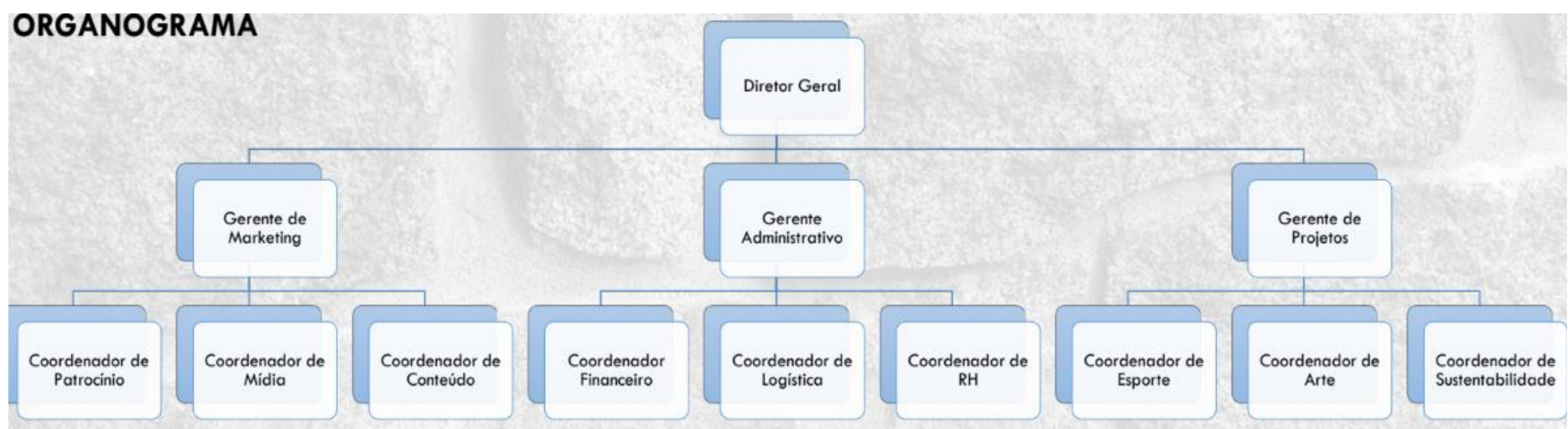




\section{Apresentação e análise dos resultados}

\section{1. $\quad$ A Organização}

A organização é composta por 12 integrantes que se dividem com o objetivo de realizar projetos. Além desses integrantes, a equipe conta também com o auxílio de voluntários em suas ações, apoio de empresas parceiras que auxiliam nas coletas e doam aparato necessário para a realização de eventos.

Os projetos tiveram início em agosto de 2016 e não pararam desde então, o projeto inicial foi o Torneio Stone House de Surf que teve uma repercussão muito maior do que o esperado. Tendo em vista que com a visibilidade adquirida era possível conscientizar um grande número de pessoas, a organização resolveu dar início às ações e projetos voltados para o tema sustentabilidade.

A organização passou a promover eventos esportivos e artísticos abordando temas ambientais, assumindo que o esporte responsável pelo pontapé inicial da organização foi o surf, que é praticado em uma atmosfera totalmente natural. Isso possibilita que os praticantes vejam a atual situação das praias e do mar em constante degradação por meio de resíduos de diversos tipos.

A seguir é possível ver uma linha do tempo e identificar os projetos ocorridos até o momento atual. 


\begin{tabular}{|c|c|c|c|c|c|}
\hline Jun 2016 & Set 2016 & Jun 2017 & Jul 2017 & $\operatorname{Jan} 2018$ & Abr 2018 \\
\hline $\begin{array}{l}1^{\circ} \text { Torneio } \\
\text { Stone House } \\
\text { Projeto inicial } \\
\text { de } \\
\text { confraternizaç } \\
\text { ão entre } \\
\text { surfistas de } \\
\text { ipanema. }\end{array}$ & $\begin{array}{l}\text { Festa } 1^{\circ} \\
\text { Torneio } \\
\text { Festa com o } \\
\text { objetivo de } \\
\text { premiar e } \\
\text { festejar o } \\
\text { sucesso do } \\
\text { primeiro } \\
\text { torneio }\end{array}$ & $\begin{array}{l}2^{\circ} \text { Torneio } \\
\text { Stone House } \\
\text { Inclusão da } \\
\text { categoria } \\
\text { Feminino }\end{array}$ & $\begin{array}{l}\text { Festa do } 2^{\circ} \\
\text { Torneio } \\
\text { Inclusão de } \\
\text { ações } \\
\text { Sustentáveis } \\
\text { durante o } \\
\text { evento. }\end{array}$ & $\begin{array}{l}\text { Travessia às } \\
\text { cagarras de } \\
\text { Prancha com } \\
\text { o intuito de } \\
\text { coletar o lixo. }\end{array}$ & $\begin{array}{l}\text { Replantio da } \\
\text { vegetação na } \\
\text { orla } \\
\text { Replantio da } \\
\text { vegetação } \\
\text { nativa na orla, } \\
\text { destruída } \\
\text { após o } \\
\text { carnaval. }\end{array}$ \\
\hline Jun 2018 & Jul 2018 & Ago 2018 & Set 2018 & Out 2018 & Out 2018 \\
\hline $\begin{array}{l}\text { Açäo de } \\
\text { limpeza da } \\
\text { lagoa } \\
\text { Ação conjunto } \\
\text { com a Route } \\
\text { de coleta e } \\
\text { conscientizaç } \\
\text { ão na Lagoa } \\
\text { Rodrigo de } \\
\text { Freitas. }\end{array}$ & $\begin{array}{l}3^{\circ} \text { Torneio } \\
\text { Stone House + } \\
\text { Festa } \\
\text { Maior torneio } \\
\text { realizado com } \\
\text { apoios de } \\
\text { marcas } \\
\text { expressivas e } \\
\text { pegada } \\
\text { sustentável. }\end{array}$ & $\begin{array}{l}\text { Festival Casa } \\
\text { Corais + } \\
\text { Limpeza } \\
\text { Arpoador } \\
\text { Festival } \\
\text { sustentável no } \\
\text { Espírito Santo } \\
\text { e limpeza e } \\
\text { conscientizaç } \\
\text { ão na praia do } \\
\text { Arpoador, }\end{array}$ & $\begin{array}{l}\text { Compensação } \\
\text { de CO2 + } \\
\text { Distribuição de } \\
\text { Livros } \\
\text { Replantio de } \\
\text { bananeiras. E } \\
\text { doação de } \\
\text { livros }\end{array}$ & $\begin{array}{l}\text { Coleta São } \\
\text { Conrado + } \\
\text { Festa Maré de } \\
\text { Histórias } \\
\text { Coleta em São } \\
\text { conrado e } \\
\text { Evento na } \\
\text { Redley } \\
\text { Ipanema } \\
\text { ligado ao mar. }\end{array}$ & $\begin{array}{l}\text { Projeto de } \\
\text { Consultoria } \\
\text { Sustentável } \\
\text { Estruturação } \\
\text { para reduzir } \\
\text { danos } \\
\text { ambientais } \\
\text { em eventos. }\end{array}$ \\
\hline
\end{tabular}

Figura 2 Linha do tempo de ações

Desde o primeiro evento realizado, vários outros foram acontecendo à medida que o engajamento foi tomando uma maior dimensão.

Para exemplificar destacam-se três eventos de grande relevância para o crescimento da organização e que destacam as áreas de atuação da Stone House.

\subsubsection{Campeonatos}

O Torneio Stone House surgiu com o intuito de promover uma confraternização na praia e fortalecimento da cena local do surf. O primeiro evento teve uma ótima repercussão e atualmente já foram realizadas 3 edições. $O$ torneio cresceu, contando com um público de mais de 300 pessoas presentes, assim como a capacidade da empresa de promover a sustentabilidade e a arte através do evento esportivo. 
O campeonato incluiu a categoria feminina (que ainda não é expressiva no esporte) com premiação igualitária em relação à masculina.

Marcas envolvidas em sustentabilidade deram suporte ao evento. A Banaiuka além de conceder alimentação com frutas orgânicas para os atletas, foi responsável pela compensação de gás carbônico emitido na produção de itens utilizados durante o campeonato. Essa ação se concretizou através do replantio de bananeiras em uma reserva em Mangaratiba em parceria com a Stone House.

A Capim Selo Verde, distribuiu copos e ecobags (bolsas de praia) reutilizáveis para que não houvesse uso de copos e sacolas descartáveis.

Durante o campeonato foi realizada uma coleta de lixo próxima a área do evento e também uma aula de yoga gratuita e aberta ao público.

O evento promoveu o uso de hashtags nas redes sociais principalmente no Instagram. A \#limpeseum2 teve o intuito de incentivar os presentes a limparem o entorno da área que frequentaram na praia, a \#carbonozero foi utilizada para demonstrar que seria feita a compensação de carbono através do replantio de árvores e a \#salveoscorais no ano internacional dos corais serviu para alertar sobre os efeitos das mudanças climáticas na fauna marinha, no caso, os corais.

O campeonato é seguido de um outro evento, a Festa do Torneio Stone House.

\subsubsection{Festas}

Na Festa do Torneio, as ações são evidenciadas retratando e reafirmando o espírito fundamental dos eventos realizados.

As marcas que apoiaram o campeonato dando premiação, expõem seus produtos em pequenos stands espalhados pela casa de pedra (anexo 8.3). 
A política de copos reutilizáveis foi mais uma vez aplicada. Além disso também foram dispostos no interior e na parte externa da casa diversos quadros e obras de artes envolvidas com a temática ambiental feitos por artistas locais.

O apoiador "O Peixe Fresco", que pesca de maneira seletiva e sustentável promoveu a alimentação para os presentes servindo frutos do mar.

Uma área da casa foi destinada à exposição de quadros e fotografias ligadas à \#salveoscorais e à campanha de conscientização a respeito dos danos sofridos pelos corais referentes às mudanças climáticas; grandes volumes de emissões de carbono; acidificação dos oceanos.

$\mathrm{Na}$ exposição foi possível ver fotos de corais dialogando com os trabalhos artísticos em um ambiente com a temática de praia, alguns textos explicativos e a presença de fósseis reais de corais. O biólogo Nicolas Lages, pesquisador do projeto Coral vivo foi o responsável por comandar um bate-papo relacionado ao tema.

Ao final da festa foi realizado um Show ao vivo "de surf music" encerrando o evento com a presença de uma banda e DJs.

O lixo gerado na festa foi separado e a parte reciclável teve a destinação adequada.

\subsubsection{Travessia}

Em janeiro de 2018 ocorreu a Travessia às Ilhas Cagarras que foi um evento composto por duas etapas, uma externa onde foi realizada a coleta de lixo e uma interna (dentro da casa) demonstrando o resultado da ação.

A primeira etapa teve início na praia de Ipanema, onde todos os envolvidos se encontraram e rumaram em direção à llha Comprida no Arquipélago das Cagarras. Dois barcos de apoio foram disponibilizados pela Greenboat Sportfishing para a filmagem; armazenamento de suprimentos e do lixo coletado. 
Subir na ilha é proibido, mas o ICMBio concedeu autorização para o pessoal envolvido no projeto coletar lixo deixado por visitantes ou trazido por ventos e marés.

Ao finalizar a coleta, foi realizada a triagem do lixo e posteriormente a construção de obras de arte com o mesmo. Essa ação teve como objetivo mostrar a quantidade e diversidade do lixo encontrado no local.

Após a triagem um artista plástico confeccionou trabalhos artísticos (pinturas, desenhos, objetos decorativos, esculturas) com os resíduos coletados, que foram expostos na galeria da Stone House. O trabalho foi mantido na galeria que estava aberta ao público por uma semana.

No início da noite foram transmitidas duas sessões do documentário Baía urbana que mostra a resistência da vida marinha na baía (Baía de Guanabara) poluída.

\subsubsection{Parcerias e Crescimento}

Em todos os seus projetos, a organização faz a captação do apoio de empresas que geram algum tipo de retorno para o meio em que estão inseridas, no caso da Stone House isso ocorre pela promoção de eventos esportivos como campeonatos de surf, travessias, atividades culturais como eventos musicais, gastronômicos, exposições de arte e atividades socioambientais.

Segundo (Félix, 2018):

"mobilização de recursos não é apenas assegurar recursos novos ou adicionais, mas também otimizar os recursos já existentes, aumentando a eficácia e a eficiência dos planos, além de conquistar novas parcerias e obter fontes alternativas de recursos financeiros. A captação de recursos é uma maneira de tornar ainda mais público o trabalho desenvolvido pela 
organização. Traz também ampliação da base social ou número de pessoas envolvidas, aumenta o número de voluntários; aumento de credibilidade e alavancagem dos projetos." "E o mais interessante: quando se refere a este assunto, qualquer pessoa, física ou jurídica, independentemente do seu poder de influência, pode dar uma contribuição. Afinal, o colapso ambiental que nossos filhos correm o risco de enfrentar é fruto de modelos de produção e consumo pouco inteligentes. E se existe saída, ela depende da participação de todos. (ABF, 2013)."

Houve crescimento da organização em mais de 100\% anualmente por 2 anos consecutivos, e com isso, um aumento considerável no número de ações e eventos realizados pela mesma.

"As ações são partes da gestão e não apenas pontuais. A sustentabilidade é a excelência na otimização dos recursos em busca do alcance dos objetivos. (Zenone, 2006)".

A organização atua em sustentabilidade em suas três esferas, são elas a esfera ambiental, social e econômica. O incremento no número de projetos demanda maior comprometimento dos integrantes da empresa, pois além de mais trabalho, muitas vezes eles precisam ser planejados simultaneamente.

A estrutura organizacional atual, não facilita esse processo pois ocorre em um formato antigo Funcional, não adequado à atividade da empresa que tem diversos projetos em andamento lado a lado e uma estrutura horizontalizada. Isso pode gerar ineficiência e atrasar as ações.

Assim sendo, o estudo tem como objetivo, analisar a estrutura organizacional atual e propor um redesenho, adequando-a à sua atividade atual, visando propor melhorias em seu desempenho. 
Ao definir a finalidade da pesquisa, que estaria voltada para resolver um problema concreto existente na organização, relacionado à estrutura organizacional e processos. Estes que atualmente não contribuem para o andamento dos projetos. Identificamos que o ideal seria uma investigação intervencionista. De acordo com (Vergara, 2018), esse tipo de pesquisa tem como principal objetivo "interferir na realidade estudada, para modificá-la" ... "não somente propor soluções e resoluções de problemas, mas também de resolvê-los efetiva e participativamente." (Vergara, 2018, p. 47).

Desta maneira é possível além de realizar o estudo, colocá-lo em prática através da concretização da proposta de reestruturação e adequação de processos, alinhando a força de trabalho aos projetos, ajudando a organização. Respaldando trabalho através dessa implementação em uma organização real, obtendo assim uma melhoria concreta.

\subsection{Análise de Sujeito 1}

$\mathrm{Na}$ análise da primeira pergunta direcionada à João, pode-se identificar que a estrutura atual não está presente no cotidiano da empresa. De acordo com ele, a falta de responsabilidades bem definidas é um fator que prejudica o andamento dos projetos.

O entrevistado relata insatisfação quanto ao comprometimento dos colaboradores. Enfatiza também que há falta de planejamento, organização e comunicação interna. Sugere que seria necessária uma reunião com o objetivo de melhorar essas áreas ou pedir ajuda a um consultor para uma reorganização.

A boa capacidade de avançar em diversos projetos foi salientada, apesar de que uma liderança mais eficaz poderia ser um fator chave para o melhor desempenho dos projetos. 
Acredita-se que estabelecer objetivos de curto prazo prejudicam o projeto final, embora os prazos estabelecidos sempre tenham sido cumpridos invariavelmente.

Relata que há conflitos e em geral são construtivos. Acredita que é necessário enfatizar a busca por um objetivo mútuo em prol da organização e não focar em saber quem está certo ou errado.

O entrevistado afirmou que há membros com formação em diversas áreas, mas ressalta a predominância em exatas. Esta especificidade facilita a comunicação e compreensão entre a maioria. Ressalta que é necessário identificar melhor as qualidades de cada um para alocá-los em áreas favoráveis para as competências individuais serem bem aproveitadas.

\subsection{Análise de Sujeito 2}

Tem noção da estrutura, mas também ressalta a falta de efetividade e presença da mesma e a sobreposição de áreas.

Foi relatado um desequilíbrio de responsabilidades e a ausência da estrutura organizacional no dia a dia da empresa. Cita a necessidade de uma estrutura mais adequada à atividade atual da organização.

O entrevistado ressalta que o andamento dos projetos é singular, ou seja, não avançam em projetos paralelamente. A causa citada foi a estrutura não direcionada à projetos.

Afirma que o prazo final é sempre cumprido e relaciona isso ao respeito em relação aos stakeholders.

Indica que os conflitos se concentram na parte de planejamento e acredita que por todos focarem em um projeto por vez há mais conflitos destrutivos do que 
construtivos, tendo em vista que há muitas pessoas para resolver um assunto em comum.

Ressalta que as características e especializações diversificadas dos membros da organização são uma vantagem competitiva e acredita que isso facilita a concretização de projetos.

\subsection{Análise de sujeito 3}

Sujeito três indica que possui ciência a respeito da estrutura e afirma que existe um bom diálogo entre as áreas, mas sugere que nem todas as áreas são vistas ou estão presentes no cotidiano da organização.

O entrevistado ressalta a disparidade de responsabilidades e comprometimento e indica que alguns colegas tentam suprir a falta de tempo de outros para que possam chegar a um objetivo comum.

Indicou que na sua visão os projetos andam bem e conseguem atender aos prazos, apesar disso eles ocorrem de maneira singular, ou seja, a empresa só atua em um projeto por vez.

O compromisso da organização é sempre pautado pela data de entrega, a equipe sempre conseguiu realizar tudo a tempo e nunca atrasou os projetos.

A existência de conflitos ao ver de Braune, é benéfica e na maioria das vezes estimula o surgimento de melhorias nos projetos, estimulando os membros a pensarem e resolverem conflitos. Ressalta que é muito difícil obter unanimidade, porém sempre se chega a um consenso pela decisão da maioria.

Acredita que as competências vêm sendo bem aproveitadas e que estas ressaltam que a estrutura deve levar em conta não só as aptidões técnicas de cada um, mas também o perfil da pessoa. 


\subsection{Análise dos resultados}

Os resultados obtidos foram satisfatórios, pois indicam diversos gargalos em processos causados por uma estrutura organizacional não compatível com as atividades atuais da empresa e ao modo como ela opera. Assim sendo podemos destacar alguns pontos.

A estrutura existe na teoria, mas na prática ela não é aplicada. Os entrevistados ressaltaram que há sobreposição de funções e o nível de responsabilidade nas áreas é discrepante. Salientaram a necessidade urgente de uma nova estrutura organizacional, visando gerir melhor as responsabilidades, em busca de um equilíbrio com o objetivo de obter melhorias em planejamento; organização e comunicação interna.

Os projetos ocorrem individualmente, ou seja, a empresa foca todo o seu efetivo em um processo de cada vez, isso dificulta um cronograma mais completo e diversificado. A falta de liderança e de uma estrutura que comporta a execução de diversos projetos simultaneamente foram citadas pelos entrevistados.

O cumprimento de prazos foi indicado como algo positivo, mas isso se deve ao fato de a empresa trabalhar em um projeto de cada vez, o que atrapalha seu crescimento e desperdiça potencial. Existe dificuldade no estabelecimento de metas de curto prazo. A falta dessas metas faz com que se adie processos durante o planejamento, que acabam prejudicando o resultado final dos projetos.

Foi consenso entre os entrevistados o fato de haver muitos conflitos na organização. Há conflitos construtivos e destrutivos durante os projetos. A presença de um grande número de pessoas para resolver tarefas simples dentro dos projetos, acaba atrapalhando ao invés de ajudar.

Discussões parar ver quem está com a razão em relação ao outro, se sobrepondo solução da questão em prol da organização como um todo, geram conflitos destrutivos. 
Os entrevistados concordam que possuir membros de diversas áreas na organização é um ponto forte que precisa ser otimizado. O melhor aproveitamento seria proveniente da identificação de competências chave e da alocação dos indivíduos em projetos de acordo com suas expertises. Isso gera maior facilidade na concretização de projetos, gerando uma vantagem competitiva.

De acordo com o referencial teórico pode-se identificar a presença de indicadores que demonstram a ineficácia da estrutura organizacional estudada. Quatro dos cinco indicadores criados por (Kerzner, 2011) foram explicitados nas entrevistas, são eles:

2 Especificações de desempenho não atendidas

3 Especialistas mal explorados e sobrecarregados

4 Indivíduos culpando uns aos outros por atrasos

5 Indivíduos insatisfeitos com a realização de projetos

Foi constatado a partir daí que seria necessária a reestruturação da organização. Para otimizar o desempenho da organização é necessário avaliar seu potencial de recursos humanos e a atividade fim da organização.

A ampliação do número de projetos da organização demandou mais velocidade e dinamismo para que os projetos consigam ser executados simultaneamente. A ocorrência desse andamento paralelo de projetos remete ao conceito de uma estrutura projetizada e também da flexível proposta por Tachizawa, que se mostra pertinente nesse caso. Assume-se que a rápida reformulação da estrutura é necessária para suprir essa demanda por novos projetos.

A falta de comprometimento e responsabilidades foram fatores decisivos na reestruturação, o peso de estar a frente de um projeto deve promover um maior senso de responsabilidade nos gerentes e também em seus ajudantes. Com a nova estrutura será possível identificar os responsáveis por erros nos projetos. 
A estrutura projetizada foi montada. Os projetos possuem cada um o seu gerente, que poderá requisitar o número de colaboradores que julgue necessário para o planejamento e execução de seu projeto.

As tarefas e responsabilidades atribuídas ao gerente estão relacionadas no Anexo 8.2.

A nova estrutura criada foi apresentada aos colaboradores no seguinte formato:

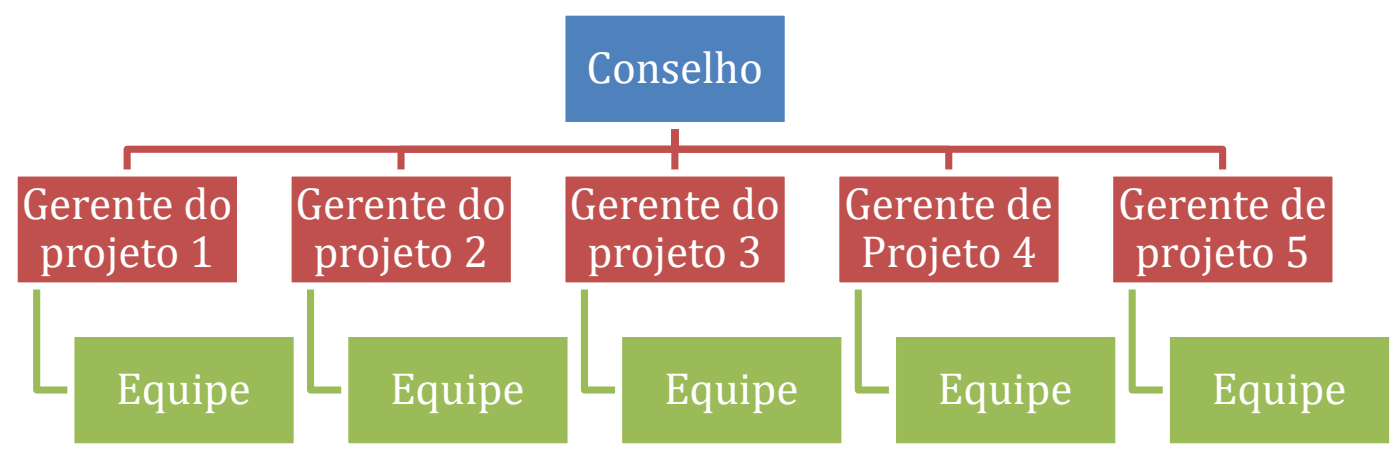

Figura 3 Nova Estrutura

É possível notar que os gerentes de projeto agora têm maior responsabilidade, tendo em vista que na estrutura anterior os projetos não possuíam um líder formal.

Os gerentes irão compor suas equipes de acordo com a demanda de cada projeto especificamente. Serão responsáveis por estipular metas de curto prazo e cobrar seus subordinados, estipulando métricas de desempenho para que o projeto prossiga da melhor maneira possível.

Os fatores humanos e pessoais são levados em conta nesse modelo. A escolha de pessoas para compor a equipe será proposta pelo gerente. Assim será possível que cada projeto tenha uma equipe com alta sinergia buscando maior eficiência e eficácia. 
As equipes de cada projetos serão menores que a anterior que contava com 12 integrantes. As decisões, por sempre buscar o consenso eram demoradas, tendo em vista que obter um consenso entre 12 integrantes é uma tarefa que demanda mais tempo. Nesse novo modelo será possível tomar decisões mais facilmente e em um período menor, tonando o processo decisório mais ágil, assim como a concretização de projetos e ações.

Com a proposta de nova estrutura os integrantes estarão cientes da mesma, essa conscientização diverge do modelo antigo que apesar de existir, não era levada em conta pelos integrantes. Estes não eram direcionados adequadamente, o que reduzia o aproveitamento de potencial em cada área. A flexibilização é possível nesse formato, os envolvidos em cada projeto podem ser realocados de acordo com a necessidade de cada momento.

A estrutura desenvolvida nesse projeto foi apresentada em uma reunião onde todos os colaboradores estavam presentes, apresentando os conceitos de estrutura organizacional e suas especificidades para todos. Houve abertura para questionamentos e dúvidas a respeito do funcionamento da nova estrutura, estes foram respondidos e sanadas imediatamente.

Os membros da organização aprovaram a implementação da nova estrutura que já passou a gerar mudanças principalmente no número de projetos da organização e na otimização do potencial da mesma.

O direcionamento adequado para cada projeto promoveu senso de direção aos que alegavam não saber o que fazer. A cobrança pelos gerentes de projetos, que são responsáveis pelo planejamento e execução, otimizou o trabalho da equipe.

Foi possível estabelecer um cronograma diversificado e atuar em diversas áreas simultaneamente, o que causou um incremento no número de projetos e ações realizadas pela organização. 
Não. A gente chegou a

Atualmente você
tem plena noção
da estrutura? No
dia a dia da
empresa e ela se
mostra presente
integralmente?
Explique.

Você está satisfeito com o comprometimento e responsabilidade praticado em todas as áreas? Se não, o que você acha que poderia resolver essa questão?

Os projetos
conseguem
avançar de
maneira
independente? Se
não, quais as
barreiras para que
isso ocorra?

Os projetos sempre têm seus prazos cumpridos dentro das áreas da organização? Se não, por que motivos?

montar uma estrutura, mas ela não

corresponde ao que

fazemos no dia a dia.

Falta direcionamento e responsabilidades para cada parte da empresa, sinto que isso é

prejudicial e atrasa o avanço da empresa.

Não estou satisfeito. A

Falta de Organização, planejamento e comunicação são os principais fatores a serem levantados. Acho que para resolver essa questão seria necessário nos reunirmos com esse objetivo ou até pedir a ajuda a um consultor para nos reorganizarmos quanto a isso.
Nós trabalhamos muito focados no prazo final, não temos o costume de estabelecer objetivos de curto prazo. Porem muitas vezes há etapas que são esquecidas e acabam prejudicando o resultado final. $\mathrm{Na}$ minha opinião isso se deve à essa dificuldade de estipular metas de curto prazo.

Nós trabalhamos muito focados no prazo final, não temos o costume de estabelecer objetivos de curto prazo. Porem muitas vezes há etapas que são esquecidas e acabam prejudicando o resultado final. $\mathrm{Na}$ minha opinião isso se deve à essa dificuldade de estipular metas de curto prazo.
Tenho noção, só que não é tão efetiva pela nossa dimensão. Há sobreposição entre funções e áreas e isso é prejudicial.
Algumas pessoas estão tendo responsabilidades bem maiores, e as funções não estão bem definidas. Precisamos de uma estrutura melhor, ou seja, mais adequada às nossas atividades.

\section{A responsabilidade de todas as áreas não é igual, pois por ser um grupo grande, há diferenças de disponibilidades ao dia de cada membro, assim sendo, alguns colegas precisam suprir a falta de tempo de outros. Esse é um ponto a ser melhorado. Talvez colocando mais pessoas em cada coordenadoria.}

Sim. Sempre temos as datas cumpridas, temos muita responsabilidade com nossos apoiadores e nosso público, acreditamos que isso representa o respeito que temos com relação aos clientes e apoiadores.
Procuramos definir uma data rapidamente ao dar início ao projeto. Isso faz com que a maioria se comprometa em realizá-lo a tempo, tudo fluiu nos últimos projetos como o esperado apesar de alguns imprevistos.
Os projetos têm andado bem, apesar disso eles não andam paralelamente e sim de maneira individual, focando em um projeto por vez.
Tenho total noção da presente nos projetos. diálogo entre as áreas porem é difícil de notar todas as áreas presente.
Focamos em um projeto divisão geral da empresa e não por projeto, isso complica o andamento de projetos paralelamente.

.




\begin{tabular}{|c|c|c|c|}
\hline $\begin{array}{l}\text { Qual a sua } \\
\text { percepção a } \\
\text { respeito de } \\
\text { conflitos durante } \\
\text { os projetos, há } \\
\text { muitos conflitos? } \\
\text { Se sim, em que } \\
\text { medida eles } \\
\text { ajudam ou } \\
\text { atrapalham o } \\
\text { andamento do } \\
\text { projeto? }\end{array}$ & $\begin{array}{l}\text { Sempre tem conflitos, } \\
\text { isso é um lado positivo, } \\
\text { pois muitas vezes os } \\
\text { conflitos vêm pra } \\
\text { agregar, trazendo } \\
\text { pontos de vista } \\
\text { diferentes, melhorando } \\
\text { a compreensão e } \\
\text { facilitando o andamento } \\
\text { dos projetos. Na minha } \\
\text { opinião eles mais } \\
\text { ajudam do que } \\
\text { atrapalham. Acredito } \\
\text { que é necessário } \\
\text { conflitar buscando um } \\
\text { objetivo mútuo. } \\
\text { Buscando a verdade } \\
\text { pelos dois lados e não } \\
\text { para ver quem está } \\
\text { certo. }\end{array}$ & $\begin{array}{l}\text { Por essa divisão ainda } \\
\text { focamos em um projeto } \\
\text { de cada vez, esses } \\
\text { conflitos existem mais } \\
\text { na parte de } \\
\text { planejamento, acredito } \\
\text { que se houver uma } \\
\text { mudança estrutural os } \\
\text { conflitos negativos } \\
\text { serão reduzidos. }\end{array}$ & $\begin{array}{l}\text { Os conflitos existem e } \\
\text { acredito que nós } \\
\text { lidamos muito bem com } \\
\text { os conflitos, apesar dos } \\
\text { membros divergirem } \\
\text { em opiniões, sempre } \\
\text { conseguimos chegar a } \\
\text { um consenso apesar de } \\
\text { ser difícil obter } \\
\text { unanimidade. Os } \\
\text { conflitos em sua maioria } \\
\text { são benéficos pois os } \\
\text { questionamentos } \\
\text { servem para que haja } \\
\text { reflexão e melhorias nos } \\
\text { projetos. }\end{array}$ \\
\hline $\begin{array}{l}\text { Você acha que as } \\
\text { competências e } \\
\text { especializações } \\
\text { de cada membro } \\
\text { estão sendo } \\
\text { aproveitadas } \\
\text { corretamente e de } \\
\text { maneira ampla na } \\
\text { organização? } \\
\text { Explique. }\end{array}$ & $\begin{array}{l}\text { Não. Acho que } \\
\text { possuímos uma ampla } \\
\text { concentração de } \\
\text { membros de exatas. } \\
\text { Isso é positivo pela } \\
\text { facilidade de conversas } \\
\text { e rápido entendimento } \\
\text { entre as pessoas. Porem } \\
\text { muitas vezes } \\
\text { poderíamos nos unir } \\
\text { para entender os } \\
\text { pontos fortes de cada } \\
\text { um e se ajudar } \\
\text { mutuamente para que } \\
\text { as pessoas não se } \\
\text { sintam recuadas a agir } \\
\text { por falta de noção em } \\
\text { como podem atuar e } \\
\text { usar as próprias } \\
\text { habilidades em prol da } \\
\text { organização. }\end{array}$ & $\begin{array}{l}\text { Sim, temos um corpo } \\
\text { bem diversificado entre } \\
\text { engenheiros, } \\
\text { administradores, } \\
\text { designers, oceanógrafos } \\
\text { e cada um vem com sua } \\
\text { bagagem de vida, o que } \\
\text { melhora o desempenho } \\
\text { de nossos projetos e } \\
\text { facilita muito conseguir } \\
\text { o que precisamos para } \\
\text { nossos projetos }\end{array}$ & $\begin{array}{l}\text { As competências vêm } \\
\text { sendo aproveitadas } \\
\text { principalmente por } \\
\text { decidirmos o local de } \\
\text { alocação de acordo com } \\
\text { o perfil e aptidão de } \\
\text { cada um. }\end{array}$ \\
\hline
\end{tabular}




\section{Conclusões}

A identificação de gargalos na estrutura organizacional da Stone House com a finalidade de aplicar melhorias, era o objetivo central do trabalho.

A estrutura organizacional antiga foi analisada assim como o modelo de negócio da organização. Essa análise foi baseada nas entrevistas semiestruturadas respondidas por diversos gestores da organização, expostas no capítulo quatro. Com base na pesquisa foi possível identificar a necessidade de uma reestruturação organizacional.

Com base nos conceitos apresentados no referencial teórico por Kerzner e Tachizawa, foi possível estruturar o planejamento e a execução de uma mudança estrutural na organização. Pautada na análise de entrevistas e relacionada com o referencial teórico, exposto no capítulo dois, que foi composto através de estudos a respeito de estruturas organizacionais e organizações flexíveis, indicadas especificamente para a aplicação em empresas com alta demanda por projetos. Assim foi possível redesenhar a estrutura organizacional otimizando os processos e projetos.

Antes das mudanças, a organização só conseguir focar em um projeto por vez, o que limitava o cronograma a no máximo (historicamente) executar três projetos anualmente.

O redesenho teve como finalidade adequar o funcionamento da empresa à sua atividade fim. Isso se deu através da mudança para uma estrutura por projetos ou projetizada.

A proposta de uma nova estrutura organizacional foi apresentada a todos os colaboradores da empresa em uma reunião. Nesta, foi montado um plano de 
reestruturação e explicado o conceito e as teorias em que a nova estrutura foi embasada.

Os colaboradores da organização se solidarizaram em relação à mudança de estrutura. Por consenso decidiram aplicá-la e assumir mais responsabilidades do que na estrutura anterior. Se mostraram satisfeitos após as medidas tomadas com base neste trabalho e relataram melhora em sua produtividade, gerando um impacto positivo para a organização. Isso se deu principalmente pela responsabilização dos gerentes pelos projetos, que acaba se transferindo às equipes, através de objetivos de curto prazo em um cronograma a ser seguido. Desta forma gerou-se maior comprometimento e indicou um norte a ser seguido por membros que se sentiam "soltos" ou mal aproveitados.

Atualmente pode-se identificar o incremento de número de projetos e na eficiência e eficácia em relação ao planejamento e execução de eventos. $O$ andamento paralelo de projetos fez com que o cronograma da empresa crescesse de três para até seis projetos anualmente (esperado para o ano de 2019) ou seja, um crescimento de cem por cento na capacidade da empresa realizar ações.

Os projetos atuais em andamento são os seguintes:

- Reforma do Bowl (pista de sk8) da Lagoa

- Travessia eco às praias selvagens

- Evento sustentável em parceria com a Mango Lab.

- Consultoria Sustentável à festa Baixo Prado

- Replantio na reserva Stone em parceria com a Banaiuka

- Consultoria Sustentável à festa It's On

A organização foi beneficiada pela pesquisa e proposta de otimização de recursos através da reestruturação. Assim sendo, pode-se concluir que o trabalho foi realmente relevante para a organização, alinhando teoria e prática, esse respaldo é 
demonstrado principalmente pelas medidas terem surtido efeito positivo imediato em uma organização verídica; em atividade e desenvolvimento.

Foi muito gratificante poder contribuir para o crescimento e desenvolvimento de uma organização pertencente setor 2.5, que sempre tem como objetivo gerar algum retorno positivo à sociedade em seus projetos e ações. 


\section{Referências Bibliográficas}

ABF. (2013). Associação Brasileira de Franchising. Fonte: Portal do franchising: https://www.portaldofranchising.com.br/artigos-sobre-franchising/sustentabilidade-novarejo/

Félix, R. G. (2010). www.administradores.com.br. Fonte: Administradores: http://www.administradores.com.br/artigos/cotidiano/a-questao-da-sustentabilidade-eo-terceiro-setor/37769/

Félix, R. G. (2018). www.administradores.com.br. Fonte: http://www.administradores.com.br/artigos/cotidiano/a-questao-da-sustentabilidade-eo-terceiro-setor/37769/

Instituto Nacional do Empreendedorismo e Inovação. (s.d.). Fonte: inei.org.br: http://inei.org.br/aceleradora25/o-que-e-o-setor-2.5

Kerzner, A. (2011). Gerenciamento de projetos - Uma abordagem sistemica para planejamento e controle. Edgard Blucher Ltda.

Meo, L. (2015). Empresas Sociais, A importância de auto-regulamentação para o desenvolvimento do setor 2.5). Rio de Janeiro.

Sucupira, G. A. (2015). Desafios de Empreender Negócios Sociais no Brasil. Rio de Janeiro: PUC-Rio.

Takizawa, T. (1997). Organização Flexível. Atlas S.A.

Vergara, S. C. (2018). Projetos e Relatórios de Pesquisa Em Administração. Atlas.

Yunus, M. (2010). Fonte: Yunus Negócios Sociais Brasil: https://www.yunusnegociossociais.com

Zenone, L. C. (2006). Marketing Social. Thomson. 


\section{$7 \quad$ Anexos}

\subsection{Roteiro}

1: Atualmente você tem plena noção da estrutura? No dia a dia da empresa e ela se mostra presente integralmente? Explique.

2: Você está satisfeito com o comprometimento e responsabilidade praticado em todas as áreas? Se não, o que você acha que poderia resolver essa questão?

3: Os projetos conseguem avançar de maneira independente? Se não, quais as barreiras para que isso ocorra?

4: Os projetos sempre têm seus prazos cumpridos dentro das áreas da organização? Se não, por que motivos?

5: Qual a sua percepção a respeito de conflitos durante os projetos, há muitos conflitos? Se sim, em que medida eles ajudam ou atrapalham o andamento do projeto?

6: Você acha que as competências e especializações de cada membro estão sendo aproveitadas corretamente e de maneira ampla na organização? Explique. 


\subsection{Processos}

Agora com a nova estrutura, também é necessário mudar alguns processos. Algumas sugestões dadas ao conselho da organização foram as seguintes:

Cada Gerente de projetos deverá apresentar para o grupo inteiro em reunião, um termo de abertura como um escopo do projeto definindo-o.

Listar tarefas abrangentes para só depois indicar em que partes do projeto ele precisará de ajuda e de quantos participantes seriam necessários no projeto.

Selecionar dentre os que estiverem dispostos a equipe com a qual ele deseja trabalhar no projeto.

O Gerente deverá estipular metas de curto prazo e será o responsável pela cobrança de resultado dos colaboradores que participarão do projeto. Será necessário traçar um cronograma.

\subsection{A Casa de Pedra}

Construída em 1936, a casa é símbolo do bairro de Ipanema e patrimônio histórico do Rio de Janeiro.

É onde os projetos surgiram, centro dos encontros, reuniões e confraternizações. Hoje parte importante dos projetos abrigando os eventos.

A casa comporta janelas com vitrais e seu exterior é todo composto por pedras pesadas.

Foi residência do escultor e joalheiro Caio Mourão e nos anos 60 foi cenário de filmes do Cinema Novo. 
Na época áurea da bossa nova, foi muito utilizada para reuniões por ícones como Vinícius de Moraes e Carlos Lyra.

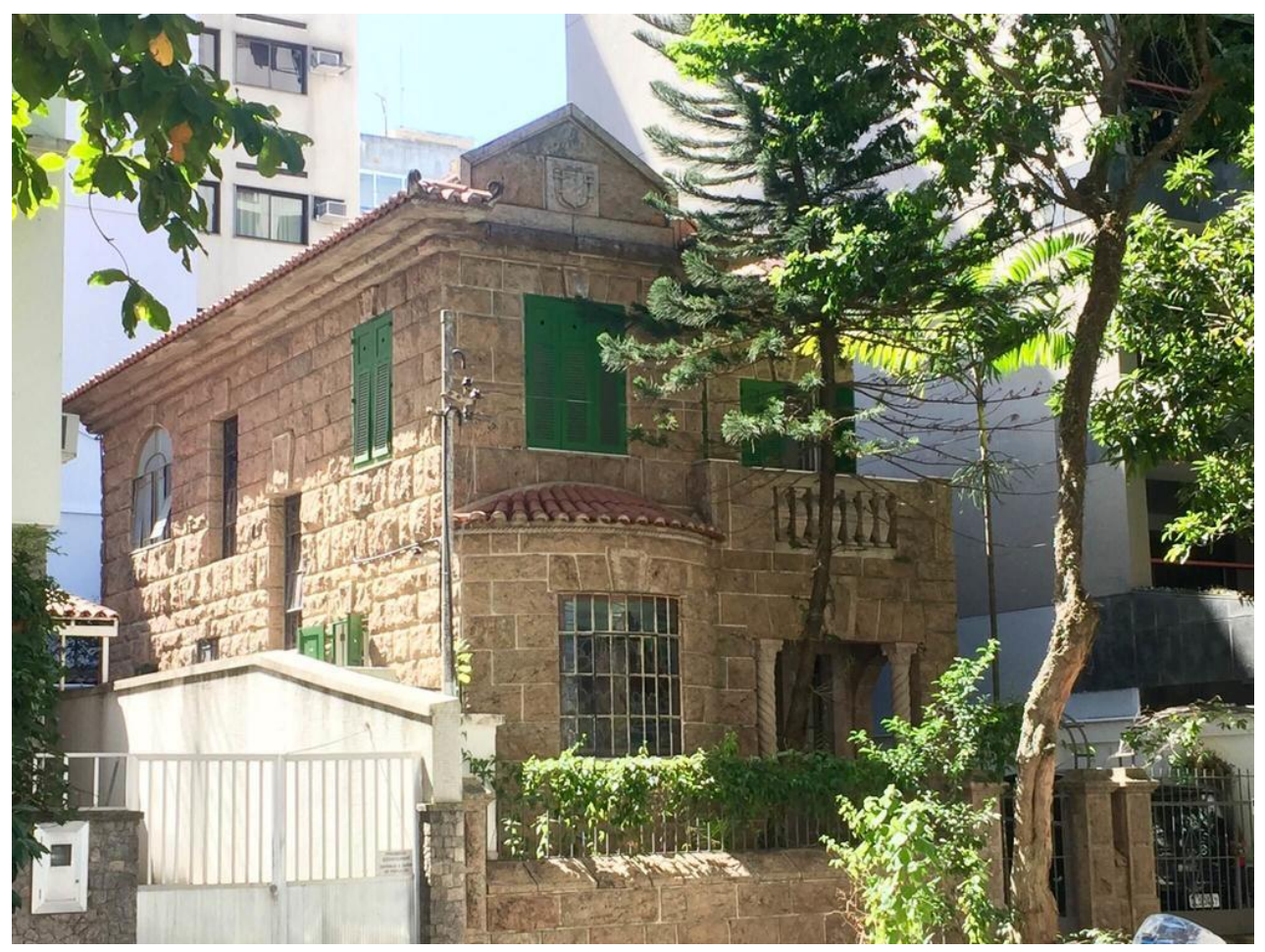

Figura 4 Stone House; Fonte: Acervo Stone House

\subsection{Fotos nos eventos}

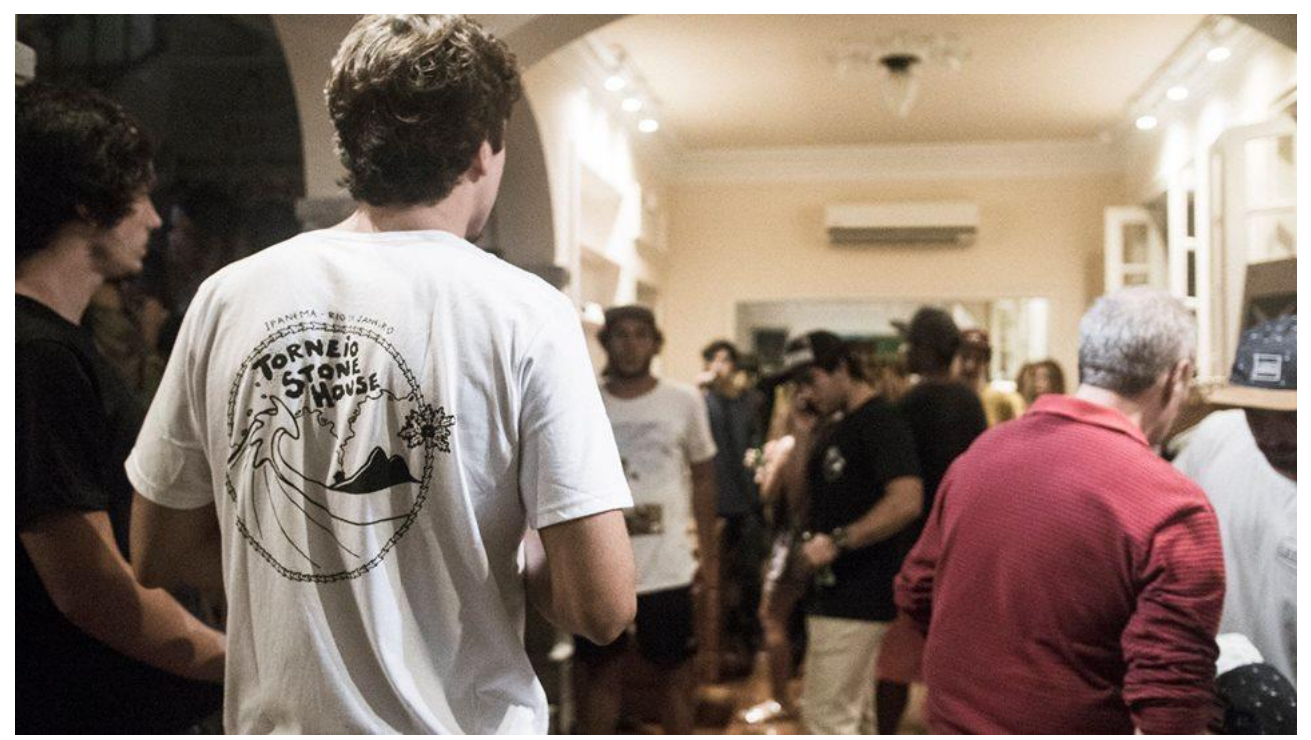

Figura 5 Festa do Campeonato; Fonte: Acervo Stone House 


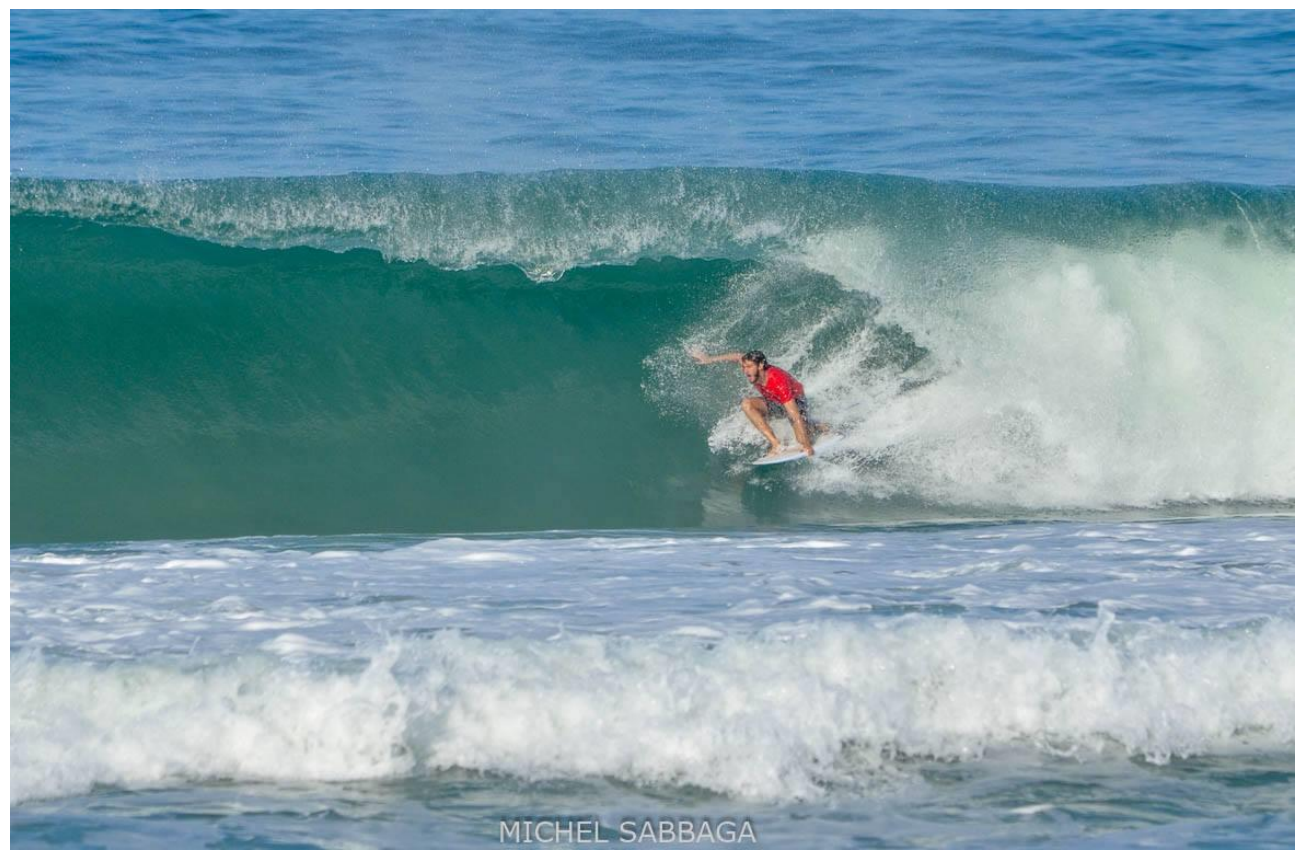

Figura 6 Tubo durante o campeonato; Fonte: Acervo Stone House

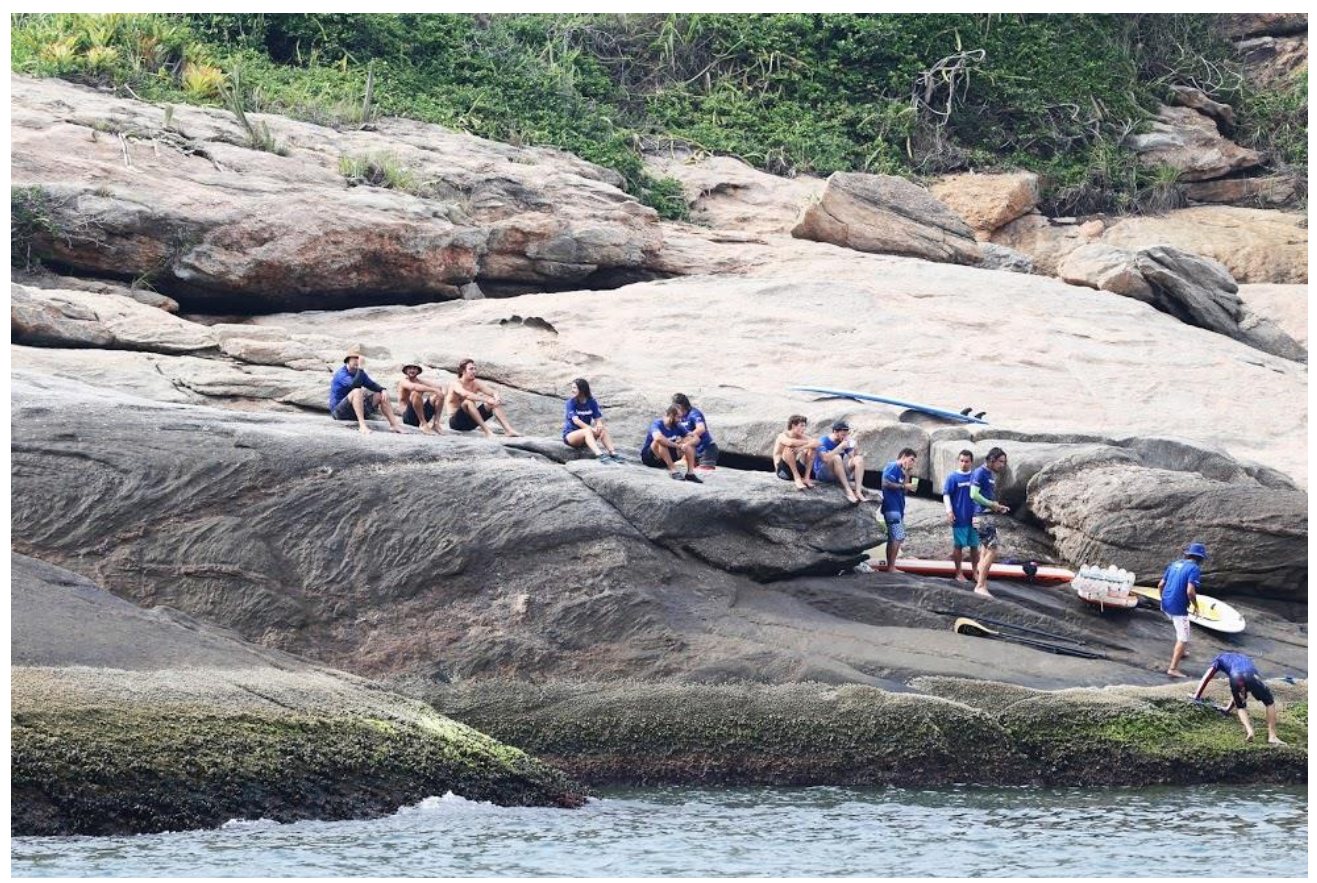

Figura 7 Chegada da travessia; Fonte: Acervo Stone House 


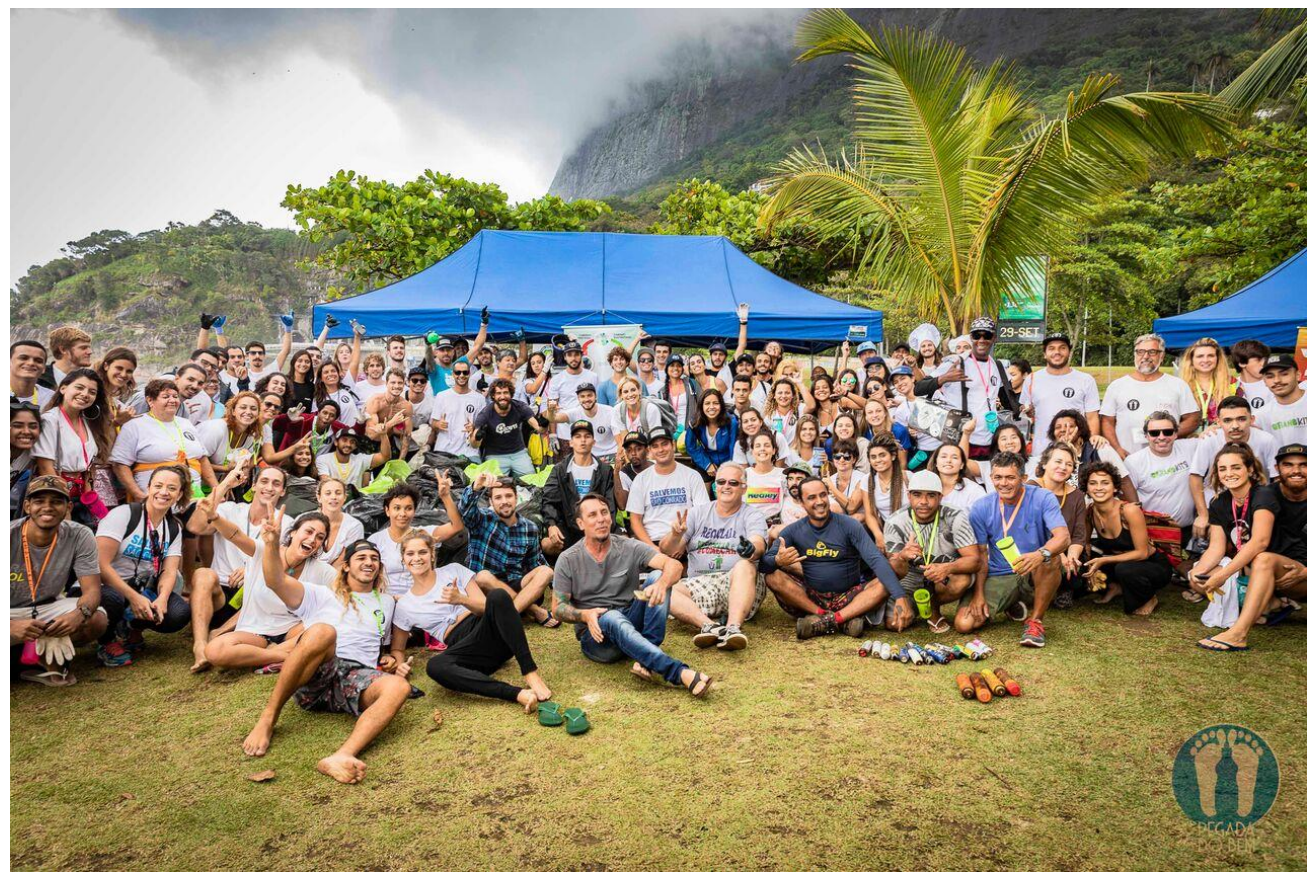

Figura 8 Pegada do bem; Fonte: Acervo Stone House

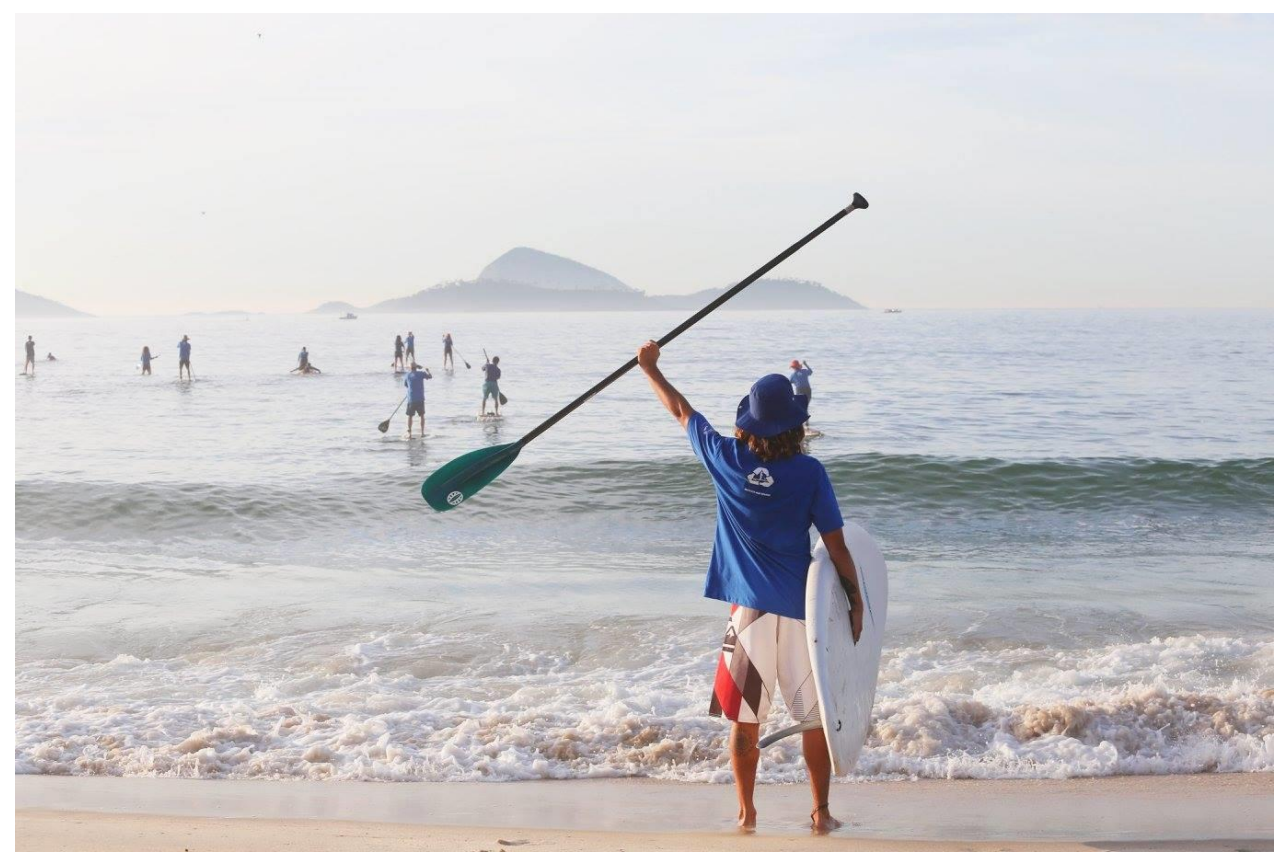

Figura 9 Saída da travessia; Fonte: Acervo Stone House 